\title{
Evaluation of Seed and Soil Treatments with Novel Bacillus subtilis Strains for Control of Soybean Root Rot Caused by Fusarium oxysporum and F. graminearum
}

\author{
J. X. Zhang, A. G. Xue, and J. T. Tambong, Eastern Cereal and Oilseed Research Centre, Agriculture and Agri- \\ Food Canada, 960 Carling Ave., Ottawa, ON, K1A 0C6, Canada
}

\begin{abstract}
Zhang, J. X., Xue, A. G., and Tambong, J. T. 2009. Evaluation of seed and soil treatments with novel Bacillus subtilis strains for control of soybean root rot caused by Fusarium oxysporum and F. graminearum. Plant Dis. 93:1317-1323.

Fusarium root rot is an important disease of soybean in Ontario, Canada. This study is to select antagonistic bacterial agents as effective alternatives to chemical pesticides for the control of root rots caused by Fusarium oxysporum and F. graminearum. Twenty-two Bacillus subtilis strains from soybean and corn roots were tested in dual cultures for inhibition of mycelial growth of $F$. oxysporum and $F$. graminearum. All strains significantly reduced mycelial growth of $F$. oxysporum by approximately 17 to $48 \%$ and of $F$. graminearum by 10 to $32 \%$. Ten $B$. subtilis strains selected based on their larger fungal inhibition zones were evaluated against macroconidial germination. These strains inhibited the spore germination of $F$. oxysporum by 20 to $48 \%$ and of $F$. graminearum by 14 to $32 \%$ in cell-free filtrates. Under greenhouse conditions, the efficacy of seed and soil treatments with $B$. subtilis strains against the two Fusarium root rot pathogens was evaluated based on root rot severity, seedling emergence, plant height, and root dry weight. Six B. subtilis strains (SB01, SB04, SB23, SB24, SB28, and SB33) from soybean roots and two strains (CB01 and $\mathrm{CH} 22$ ) from corn roots significantly reduced the severity of the two Fusarium root rots in seed or soil treatments. Strains SB01, SB04, SB23, and SB24 were the most effective treatments against both pathogens in either seed or soil treatment. When applied as seed treatments, these four strains reduced root rot severity by 43 to $63 \%$ and increased emergence by 13 to $17 \%$, plant height by 9 to $18 \%$, and root dry weight by 8.4 to $19 \%$. When used as soil treatments, they reduced root rot severity by 68 to $74 \%$ and increased emergence by 14 to $18 \%$, plant height by 11 to $23 \%$, and root dry weight by 16 to $24 \%$. These results suggest that the novel strains of $B$. subtilis identified in this research can be effective alternatives to fungicides in managing Fusarium root rots of soybean, and a greater level of efficacy may be achieved when they were used as soil treatments than seed treatments.
\end{abstract}

Fusarium oxysporum Schltdl. and $F$. graminearum Schwabe are major pathogens of soybean root rots in Ontario, Canada $(9,26)$. A survey on pathogen profile of soybean root rots in eastern Canada demonstrated that Fusarium spp., including $F$. oxysporum and $F$. graminearum, represent $68 \%$ of pathogens responsible for root rots in 2002 (A. Lévesque, http://www.soybean. on.ca). Soybean yield losses attributed to Fusarium root rots were 7,000 metric tons in Canada and 80,000 metric tons in the United States in 1998 (28). Resistant cultivars remain the most economical and longterm approach for controlling the disease but commercial cultivars with high level of resistance to Fusarium root rot are not yet available to soybean growers $(17,26)$. Currently, pesticide seed treatment and cultural practices such as crop rotation, selec-

Corresponding author: A. G. Xue

E-mail: axue @agr.gc.ca

Accepted for publication 2 August 2009

doi:10.1094/PDIS-93-12-1317

(C) 2009 Her Majesty the Queen in Right of Canada, Department of Agriculture and Agri-Food, Government of Canada tion of high quality seed, and use of fields with good soil fertility are employed as management strategies against these root rot pathogens (17). The continuous use of chemicals at high concentrations has developed pathogen fungicidal resistance and impacted nontarget species and the environment with potential public health concerns $(7,10)$. There is a growing need for alternative control measures that are environmentally friendly for control of Fusarium root rots in soybean.

The use of microorganism to control plant diseases is a promising strategy and has potential for managing Fusarium rot root diseases of soybean. Compared with chemical control, using microbial agents to control plant pathogens can be an ecofriendly and cost-effective component of an integrated management program (14). Because biocontrol agents are usually isolated from natural fields, the risk of environmental contamination is limited. In addition, the bioagents isolated from specific crop roots or rhizosphere soil may colonize the root system and multiply in these rhizospheres $(3,15)$, providing longlasting and long-term effect in reducing root rots and ensuring healthy growth of current and subsequent crops.
Bacillus subtilis is a group of bacteria commonly found in various ecological niches including soil, water, and air (18). These bacteria produce endospores, which allows $B$. subtilis to resist unfavorable environmental conditions and survive long-term storage at a wide range of temperatures, and allows for easy development of reliable formulations (4). Several studies on B. subtilis have demonstrated their efficacy for controlling various root rots of crops such as Phoma root rot of pea (30), Rhizoctonia root rot of wheat (22), and Fusarium wilt of tomato (8). Some of these studies also reported that $B$. subtilis stains promoted plant growth $(22,30)$. Seed and soil treatments with $B$. subtilis have been used as common methods to deliver $B$. subtilis to various crop rhizospheres against root rot diseases. For example, soil and seed treatments with $B$. subtilis protected tomato plants against $F$. oxysporum f. sp. lycopersici $(8,21)$ and cucumber and lettuce from root rot diseases $(1,25)$. In the United States, several strains of B. subtilis have been registered for controlling major diseases of cherry, cucurbits, grape, leaf vegetables, pepper, peanut, potato, tomato, and walnut (http://www.epa.gov/pesticides/ biopesticides).

Although several biocontrol agents have been studied for controlling root rot, damping-off, seedling blight, and wilts caused by Fusarium spp. in different crops (12-14), little information exists on biocontrol of Fusarium root rots in soybean. We isolated 26 B. subtilis strains from corn and soybean roots in Ontario, which showed powerful and consistent inhibition on potato dextrose agar (PDA) plates to $F$. oxysporum and $F$. graminearum, causal agents of soybean root rot. The objective of this study was to evaluate, in replicated experiments, in vitro antagonistic activities of these B. subtilis strains in dual cultures with $F$. oxysporum and $F$. graminearum; and to determine their effectiveness to protect soybean plants against the Fusarium root rot pathogens under greenhouse conditions.

\section{MATERIALS AND METHODS}

Isolation and in vitro antagonistic activity assay of $B$. subtilis. Twenty-six $B$. subtilis strains were evaluated against root rot caused by $F$. graminearum and $F$. oxysporum. Of these strains (Table 1), four strains (CH07, $\mathrm{CH} 10, \mathrm{CH} 19$, and $\mathrm{CH} 22$ ) were isolated from corn roots and their 
inhibition of mycelial growth of $F$. graminearum was measured in a previous study (A. G. Xue, unpublished). The remaining 22 strains were selected from a pool of about 200 bacterial colonies isolated from a crop rotation experiment at the Central Experimental Farm, Ottawa, Canada in 2006. This long-term experiment was set up to determine the effects of wheat, corn, and soybean rotations on the dynamics of microorganisms in rhizospheres of the three crops. The field consisted of 72 plots ( 30 by $50 \mathrm{~m}$ ), and 24 plots were planted with each crop of wheat, corn, and soybean. Twenty plants of wheat, corn, or soybean were uprooted in each plot at the maturity. Plant roots were cut off, washed under tap water for $5 \mathrm{~min}$ to remove adhering soil, and segmented into $5-\mathrm{mm}$ pieces. Fifty root pieces were randomly selected from each plot of wheat, corn, or soybean and surface sterilized in $0.5 \%$ sodium hypochlorite (Colgate-Palmolive Inc., Toronto) for $1 \mathrm{~min}$. Five root pieces were placed in each 9-cm plate with PDA without antibiotics and incubated at $25^{\circ} \mathrm{C}$. In total, 1,200 root pieces were cultured for each crop. After a week, bacterial colonies producing inhibition zones against fungal species on the same plates were isolated and purified by single-colony streaking. Restreaking single colonies of each strain were cultured in Luria-Bertani broth (LB; $10 \mathrm{~g}$ of Bacto- tryptone, $5 \mathrm{~g}$ of Bacto-yeast extract, and 10 $\mathrm{g}$ of $\mathrm{NaCl}$ in 1 liter of distilled water) and incubated overnight at $25^{\circ} \mathrm{C}$. Aliquots of the bacterial suspension were kept at $-80^{\circ} \mathrm{C}$ in $15 \%$ glycerol $(\mathrm{vol} / \mathrm{vol})$ for longterm storage. Routinely, fresh bacterial cultures were obtained from frozen bacterial stocks before each experiment and grown at $25^{\circ} \mathrm{C}$ on LB agar medium. Bacterial strains were identified based on morphology, gram staining, $\mathrm{KOH}$, and other biochemical tests and confirmed by $16 \mathrm{~S}$ ribosomal RNA gene sequence followed by similarity search against all publicly available GenBank entries using the Basic Local Alignment Search Tool (BLAST).

No strains were selected from bacterial colonies isolated from wheat roots for a dual culture test against two Fusarium spp. because they did not produce clear inhibition zones with any fungal species on PDA plates. To select promising B. subtilis strains from more than 200 B. subtilis strains from corn and soybean roots, each of them was incubated in dual cultures against $F$. oxysporum or $F$. graminearum for a prescreening based on the size of the inhibition zone. In all, 22 promising strains (4 from corn roots and 18 from soybean roots; Table 1) were selected for in vitro experiments against $F$. oxysporum and $F$. graminearum in dual cultures. Mycelial growth inhibition was performed for all 22 strains by dual cultures on PDA with four replicates in two experiments. A 6- $\mathrm{mm}$ filter paper disc was soaked in such a bacterial suspension at $10^{7} \mathrm{CFU} \mathrm{m}{ }^{-1}$ for 2 min and placed at the center of a $9-\mathrm{cm}$ PDA plate. A 6-mm agar plug containing mycelia from a 7-day-old $F$. oxysporum or $F$. graminearum plate was placed $2 \mathrm{~cm}$ from the bacterized filter paper disc and plates were incubated at $25^{\circ} \mathrm{C}$ for 10 days. Inhibition of fungal growth was recorded by measuring the clear zone between the Fusarium agar plug and bacterized paper disc.

The effects of bacterial cell-free filtrates on the germination of macroconidia of $F$. oxysporum and $F$. graminearum were studied. Ten $B$. subtilis strains showing significant mycelial growth inhibition of both $F$. oxysporum and $F$. graminearum were selected for macroconidial germination test. The bacterial filtrates were obtained after centrifugation $(10,000 \mathrm{rpm})$ of overnight cultures and the supernatant passed through a $0.22-\mu \mathrm{m}$ filter (Millipore Corporation, Bedford, MA). The filtrates were inoculated with $F$. oxysporum or $F$. graminearum at $10^{5}$ macroconidia $\mathrm{ml}^{-1}$. Macroconidia inoculated in sterilized LB were used as a positive control. A drop of bacterial filtrate with macroconidia was microscopically examined to determine conidial germination rate per replicate by counting 250 macroconidia per slide incubated under a cover slide at $25^{\circ} \mathrm{C}$ for $24 \mathrm{~h}$.

Table 1. Effects of seed and soil treatments with Bacillus subtilis strains on Fusarium oxysporum root rot on soybean, emergence, plant growth, and root dry weight under greenhouse conditions ${ }^{\mathrm{y}}$

\begin{tabular}{|c|c|c|c|c|c|c|c|c|}
\hline \multirow[b]{2}{*}{ Strain } & \multicolumn{2}{|c|}{ Root rot severity $(0-5)$} & \multicolumn{2}{|c|}{ Seed emergence $(\%)$} & \multicolumn{2}{|c|}{ Plant height (cm) } & \multicolumn{2}{|c|}{ Root dry weight (mg/plant) } \\
\hline & Seed & Soil & Seed & Soil & Seed & Soil & Seed & Soil \\
\hline Noninoculated & 0 & 0 & 96.8 & 96.8 & 20.5 & 20.5 & 95.6 & 95.6 \\
\hline CB01 & 1.6 & 1.3 & 95.1 & 94 & 18.6 & 19.3 & 84.0 & 87.5 \\
\hline CB05 & 2.1 & 1.6 & 83.5 & 92.8 & 17.9 & 18.4 & 78.5 & 77.1 \\
\hline CB10-2 & 2.4 & 2.1 & 87.6 & 88.0 & 17.2 & 17.5 & 77.1 & 79.2 \\
\hline CB11-2 & 2.4 & 1.7 & 86.6 & 89.0 & 17.6 & 18.9 & 78.9 & 78.7 \\
\hline CGB & 2.5 & 2.0 & 86.3 & 85.3 & 17.3 & 17.3 & 80.2 & 87.5 \\
\hline $\mathrm{CH} 07$ & 2.4 & 2.2 & 88.5 & 88.8 & 17.9 & 18.1 & 77.6 & 78.9 \\
\hline $\mathrm{CH} 10$ & 2.1 & 1.9 & 88.4 & 92.1 & 16.8 & 18.0 & 76.2 & 85.7 \\
\hline $\mathrm{CH} 19$ & 1.9 & 1.7 & 91.5 & 88.5 & 18.2 & 18.9 & 81.0 & 85.6 \\
\hline $\mathrm{CH} 22$ & 1.5 & 1.0 & 94.5 & 94.5 & 18.9 & 19.7 & 83.2 & 93.1 \\
\hline SB01 & 1.1 & 0.8 & 96.3 & 96.3 & 19.2 & 19.9 & 92.6 & 98.3 \\
\hline SB04 & 1.4 & 0.9 & 94.8 & 95.9 & 19.4 & 19.1 & 91.9 & 95.1 \\
\hline SB05 & 1.9 & 1.5 & 92.8 & 93.7 & 18.4 & 18.8 & 80.7 & 79.2 \\
\hline SB06 & 2.1 & 1.4 & 91.9 & 93.7 & 19.0 & 18.9 & 83.2 & 83.7 \\
\hline SB08 & 2.2 & 1.6 & 88.5 & 93.3 & 17.7 & 18.2 & 83.6 & 93.2 \\
\hline SB09 & 2.5 & 2.1 & 81.6 & 91.8 & 16.7 & 18.3 & 73.1 & 79.7 \\
\hline SB11 & 2.1 & 1.8 & 88.1 & 90.2 & 17.7 & 18.4 & 77.7 & 80.7 \\
\hline SB14 & 2.0 & 1.6 & 88.4 & 90.7 & 18.0 & 17.8 & 80.4 & 84.3 \\
\hline SB15 & 2.1 & 1.8 & 90.1 & 90.1 & 17.8 & 18.6 & 80.5 & 82.8 \\
\hline SB16 & 2.4 & 1.7 & 84.9 & 90.6 & 18.9 & 18.6 & 79.1 & 71.4 \\
\hline SB20 & 2.1 & 2.4 & 84.9 & 89.5 & 17.2 & 17.2 & 74.5 & 78.8 \\
\hline SB23 & 1.4 & 0.9 & 94.4 & 95.2 & 19.2 & 19.8 & 85.6 & 88.6 \\
\hline SB24 & 1.0 & 0.8 & 94.8 & 94.5 & 20.1 & 20.8 & 91.3 & 94.8 \\
\hline SB25 & 2.4 & 2.0 & 92.8 & 93.7 & 17.3 & 18.6 & 76.7 & 75.6 \\
\hline SB27-1 & 2.7 & 2.3 & 87.7 & 90.0 & 17.1 & 17.5 & 75.8 & 78.2 \\
\hline SB28 & 1.8 & 1.1 & 92.6 & 90.8 & 18.6 & 18.2 & 87.0 & 88.4 \\
\hline SB33 & 1.4 & 1.2 & 93.6 & 93.9 & 18.4 & 20.0 & 84.0 & 93.0 \\
\hline Untreated & 2.8 & 2.8 & 80.1 & 80.1 & 17.1 & 17.1 & 76.4 & 76.4 \\
\hline $\mathrm{LSD}^{\mathrm{z}}$ & 0.4 & 0.3 & 7.6 & 7.5 & 1.0 & 1.1 & 7.3 & 11.2 \\
\hline
\end{tabular}

${ }^{\mathrm{y}}$ B. subtilis strains were isolated from soybean roots $(\mathrm{SB})$, corn roots $(\mathrm{CB}$ and $\mathrm{CH})$, and soybean stem $(\mathrm{CGB})$. Noninoculated $=$ healthy plants without any inoculation and Untreated = plant roots only treated with inoculum of $F$. oxysporum. Data were means of three trials.

${ }^{\mathrm{z}} \mathrm{LSD}=$ least significant difference $(P=0.05)$. 
Preparation of Fusarium inocula. $F$. oxysporum and $F$. graminearum inocula were prepared using wheat kernels as previously described (29) with minor modification. Wheat grain $(1 \mathrm{~kg})$ soaked in tap water for $8 \mathrm{~h}$ was steam autoclaved at $121^{\circ} \mathrm{C}$ at a pressure of $1.05 \mathrm{~kg} \mathrm{~cm}^{-2}$ for 60 min. Twenty agar discs ( $6 \mathrm{~mm}$ in diameter) were cut from 1-week-old $F$. graminearum or $F$. oxysporum PDA culture and added to each bag of autoclaved wheat grain, thoroughly mixed, and incubated for 3 weeks at $23^{\circ} \mathrm{C}$. The Fusarium inocula were air dried at room temperature and stored as infested wheat grain at $4^{\circ} \mathrm{C}$ until used in the greenhouse.

Preparation of bacterized seed and peat. Twenty-six B. subtilis strains, 22 strains in this study and 4 from the previous trials, were used for seed and soil treatments. To develop the bacterial formulation, B. subtilis strains were grown in LB at 21 to $23^{\circ} \mathrm{C}$ for $72 \mathrm{~h}$ with shaking at 150 $\mathrm{rpm}$. The bacterial cultures were adjusted to a concentration of $10^{8} \mathrm{CFU} \mathrm{mm^{-1 }}$ for seed or soil treatments. Sterile peat (EMD Crop BioScience) was used as the bacterial carrier or delivery substrate in seed and soil treatments. For soil treatments, sterile peat was drenched with bacterial broth cultures at the rate of $50 \mathrm{ml}$ of bacterial broth to $50 \mathrm{~g}$ of peat. Peat slurry was air dried at room temperature for $48 \mathrm{~h}$ and then processed into a powder form with a commercial blender under a fume hood. For seed treatments, $7 \mathrm{~g}$ of soybean seed were thoroughly mixed with $3 \mathrm{~g}$ of peat and $10 \mathrm{ml}\left(10^{8} \mathrm{CFU} \mathrm{ml^{-1 } )}\right.$ of B. subtilis broth culture and allowed to dry under a fume hood until seeding. The bacterized peat with $10^{8} \mathrm{CFU} \mathrm{\textrm {g } ^ { - 1 }}$ and seed with approximately $1.4 \times 10^{8} \mathrm{CFU} \mathrm{g}^{-1}$ were used for soil and seed treatment experiments, respectively, in the greenhouse within 3 days after processing.

Effects of seed and soil treatments with B. subtilis on the control of Fusarium root rot in the greenhouse. The effects of seed and soil treatments with $B$. subtilis strains on the control of $F$. oxysporum and $F$. graminearum root rots of soybean were evaluated under greenhouse conditions. Soybean cv. PS46, susceptible to both $F$. oxysporum and $F$. graminearum, was used in all greenhouse experiments. In the first two trials in 2006 and 2007, pots $(15$ by $15 \mathrm{~cm})$ were filled with steamsterilized soil mix containing $50 \%$ soil, $25 \%$ Premier potting mixes (Plantproducts, Canada), and $25 \%$ vermiculite (Plantproducts, Canada). In soil treatment experiments, six untreated soybean seeds per pot were planted together with a per-hole ( 2 $\mathrm{cm}$ deep by $2.5 \mathrm{~cm}$ in diameter) inoculation rate of $0.3 \mathrm{~g}$ of bacterized peat powder and 10 wheat grains infested with $F$. $o x$ ysporum or $F$. graminearum. The seed, bacterized peat, and wheat inoculum were thoroughly mixed in the hole with a spatula and covered by soil. In seed treatment, pots were planted only with bacterized seed and Fusarium spp. inocula. Each replicate contained one pot in soil and seed treatment experiments. In the 2008 trial, all seed and soil treatments with $B$. subtilis strains were the same as in 2006 and 2007 but used seedling trays with dimensions of 58 by 28 by $8 \mathrm{~cm}$ (Kord Products Inc., Bramalea, Ontario, Canada). Each tray consisted of 72 cells ( 4.5 by 4.5 by $5 \mathrm{~cm}$ ) and 2 seeds were planted in each cell. There were 18 plants for each replicate. Each trial for seed and soil treatments with B. subtilis had a healthy plant control without any inoculation (noninoculated) and a positive disease control inoculated with $F$. oxysporum or $F$. graminearum (untreated). Soybean seedlings were grown under a photoperiod of 16 and $8 \mathrm{~h}$ at 25 and $20^{\circ} \mathrm{C}$, respectively, in the greenhouse. Water and fertilizer were regularly applied to soybean seedlings when needed. Each treatment was replicated four times in the three trials performed during 2006 to 2008 . Root rot severity, seed emergence, plant height, and root dry weight were measured to evaluate the effects of the bacterial strains on the two Fusarium spp. 30 days after seeding in 2006 and 2007 and 14 days after seeding in 2008. Root rot severity caused by the two Fusarium spp. were evaluated with a 0 to 5 rating scale modified from a previous study (29), where $0=$ no disease, 1 = slight necrosis or a few lesions on roots with total diseased area $\leq 5 \%, 2=$ slight to moderate necrosis or lesions on roots with total diseased area $\leq 10 \%, 3=$ moderate necrosis or lesions with total diseased area $\leq 25 \%, 4=$ extensive necrosis or lesions on roots with total diseased area $\leq 50 \%$ and seedling growth is hampered, and $5=$ extensive necrosis or lesions on roots with total diseased area $\geq 50 \%$ and seedling growth seriously hampered or plant leading to death.

Statistical analysis. All data expressed as percentages were arcsine transformed $\left(\operatorname{sine}^{-1}\right) \sqrt{ } x$ before analysis of variance (ANOVA). In four control parameters of seed and soil treatments against $F$. oxysporum and $F$. graminearum, the interactions of trial year-treatment (strain) were not significant on seed emergence, plant height, and disease severity. Because root dry weights in seed and soil treatments did not show significant interactions of trial year-treatment (strain) at $P=0.01$ but only at $P=0.05$, the combined data from all trials were used for ANOVA and means were separated using the least significant difference at $P=0.05$ in the Statistical Analysis System program (SAS; SAS Institute Inc., Cary, NC).

\section{RESULTS}

Isolation and in vitro antagonistic assay of $B$. subtilis strains. Approximately 4,000 fungal and bacterial colonies were recovered from isolation of 1,440 roots of wheat, corn, and soybean plants. Initial screening identified more than 200 bacterial colonies isolated from corn and soybean roots exhibiting some degree of inhibition to Fusarium spp. or other fungal species in primary PDA plates. No bacterial colonies from wheat root tissues were found to inhibit fungal mycelial growth. In all, 22 promising B. subtilis strains (Table 1), 4 from corn roots and 18 from soybean roots, were selected for further evaluation based on the size of inhibition zone. These 22 strains, when tested for antagonistic activity against mycelial colony growth, exhibited consistent clear inhibition zones in dual cultures with $F$. oxysporum (Fig. $1 \mathrm{~A}$ and $\mathrm{B}$ ) and $F$. graminearum, and significantly $(P \leq 0.05)$ reduced colony areas of $F$. oxysporum and $F$. graminearum (Fig. 2). Cell-free filtrates of $10 \mathrm{~B}$. subtilis strains significantly $(P \leq 0.05)$ reduced macroconidial germination rates of $F$. $o x$ ysporum and $F$. graminearum (Fig. 3). In general, strains SB01, SB04, SB23, and SB24 showed better inhibition of mycelial growth (Fig. 2) and macroconidial germination (Fig. 3) of the two Fusarium spp.

Effects of seed and soil treatments with selected $B$. subtilis strains on control of Fusarium root rot in the greenhouse. No significant interactions of treatments (strains)-trial period in 2006, 2007, and 2008 were detected for seed emergence, plant height, and root rot severity $(P>0.05)$ in the seed and soil treatments against the $F$. oxysporum root rot (Table 2). However, treatment-trial period was significant for root dry weight $(P<0.05)$. The influence of the different strains on disease severity, seed emergence, plant height, and root dry weight varied significantly $(P<0.01)$ in the seed and soil treatments against $F$. oxysporum root rot. In seed treatment, the disease severity ranged from 1.0 to 2.7 , with seed emergence ranging from 81.6 to $96.3 \%$, plant height from 17.1 to $20.1 \mathrm{~cm}$, and root dry weight from 73.1 to $92.6 \mathrm{mg}$ per plant. Of the 26 bacterial strains, 18 significantly $(P<0.05)$ reduced the root rot disease severity from 2.8 in the untreated control to between 1.0 and 2.2 , a reduction of approximately 20 to $64 \%$ (Table 1). Not all strains with significant reduction in root

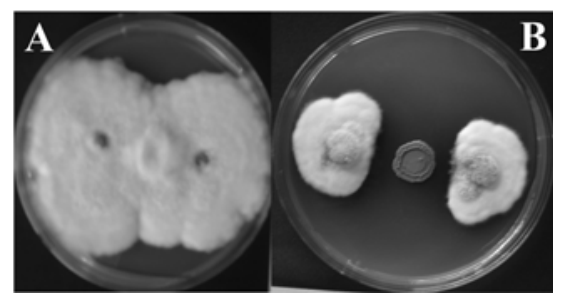

Fig. 1. Typical antagonistic interaction between Bacillus subtilis and Fusarium oxysporum in dual cultures incubated on potato dextrose agar for 10 days at $23^{\circ} \mathrm{C}$. A, Interaction between a Luria-Bertani broth-soaked filter paper disc (no bacteria) and F. oxysporum; $\mathbf{B}$, interaction between B. subtilis strain SB04 and F. oxysporum. 
rot severity provided significant increases in seed emergence, plant height, and root dry weight. Compared with the untreated strains, 13 strains significantly $(P<0.05)$ increased seed emergence, 12 increased plant height, and 5 improved root dry weight. Considering the effectiveness based on all four parameters in seed treatment against $F$. oxysporum, only five strains (SB01, SB04, SB23, SB24, and SB28) with disease severity ranging from 1 to 1.8 significantly increased seed emergence, plant height, and dry root weight. No strains stimulated greater plant height and root dry weight than those of noninoculated plants, indicating that these bacterial strains did not promote plant growth.

In the soil treatments against $F$. oxysporum root rot, disease severity ranged from 0.8 to 2.4 , seed emergence from 85.3 to $96.3 \%$, plant height from 17.2 to 20.8 $\mathrm{cm}$, and root dry weight from 71.4 to 98.3 $\mathrm{mg} /$ root (Table 1). Of the 26 strains, 25 displayed significant effectiveness $(P \leq$ 0.05 ) for controlling $F$. oxysporum root rot by soil treatment. All bacterial strains used in soil treatments, except strain SB20, significantly reduced $(P<0.01)$ severity of F. oxysporum root rot by up to $73 \%$. In all, 21 strains showed significant increases $(P$ $\leq 0.05)$ in emergence, 16 in plant height, and 8 in root dry weight. Only six strains (CH22, SB01, SB04, SB23, SB24, and SB33) provided better $F$. oxysporum root rot control that reduced disease severity by approximately 57 to $73 \%$ and significantly increased seed emergence, plant height, and root dry weight (Table 1). Similar to seed treatments, significant effect on plant growth promotion was not observed by the $B$. subtilis strains in soil treatments.
In the control of $F$. graminearum root rot, the bacterial strains resulted in significant differences $(P<0.01)$ in the reduction of disease severity and increasing seed emergence, plant height, and root dry weight in seed and soil treatments (Table 2). In addition, a significant interaction of treatment (strains)-trial period was observed only for root dry weight in soil treatment $(P<0.05)$ (Table 2$)$. In seed treatment (Table 3), 21 of the 26 strains significantly $(P \leq 0.05)$ reduced disease severity, 11 increased seed emergence, 7 showed an increase in plant height, and 4 increased root dry weight compared with the untreated control. Four strains (SB01, SB04, SB23, and SB24) significantly reduced disease severity with significant increases in seed emergence, plant height, and root dry weight in the seed treatment against $F$. graminearum root rot (Table 3 ).

In soil treatments against $F$. graminearum root rot, all 26 strains significantly reduced $F$. graminearum root rot disease severity by approximately 12 to $74 \%$ (Table 3 ). In response to the severity reduction, 19 of the 26 strains significantly increased seed emergence, and treatments of 8 strains increased plant height while 7 enhanced root dry weight over the untreated strains (Table

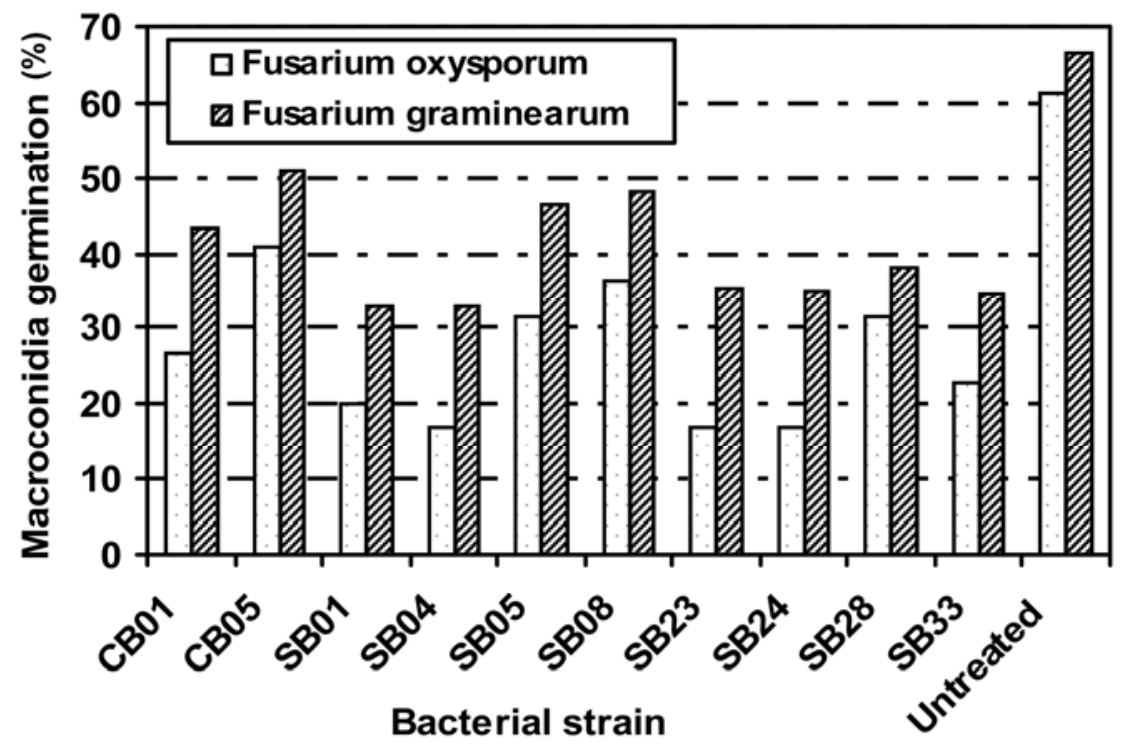

Fig. 3. Percent macroconidial germination of Fusarium oxysporum and F. graminearum in Bacillus subtilis cell-free filtrates. B. subtilis strains isolated from soybean roots (SB) and corn roots (CB). Least significant difference $=8.4$ at $P \leq 0.05$ for $F$. oxysporum and 7.6 for $F$. graminearum.

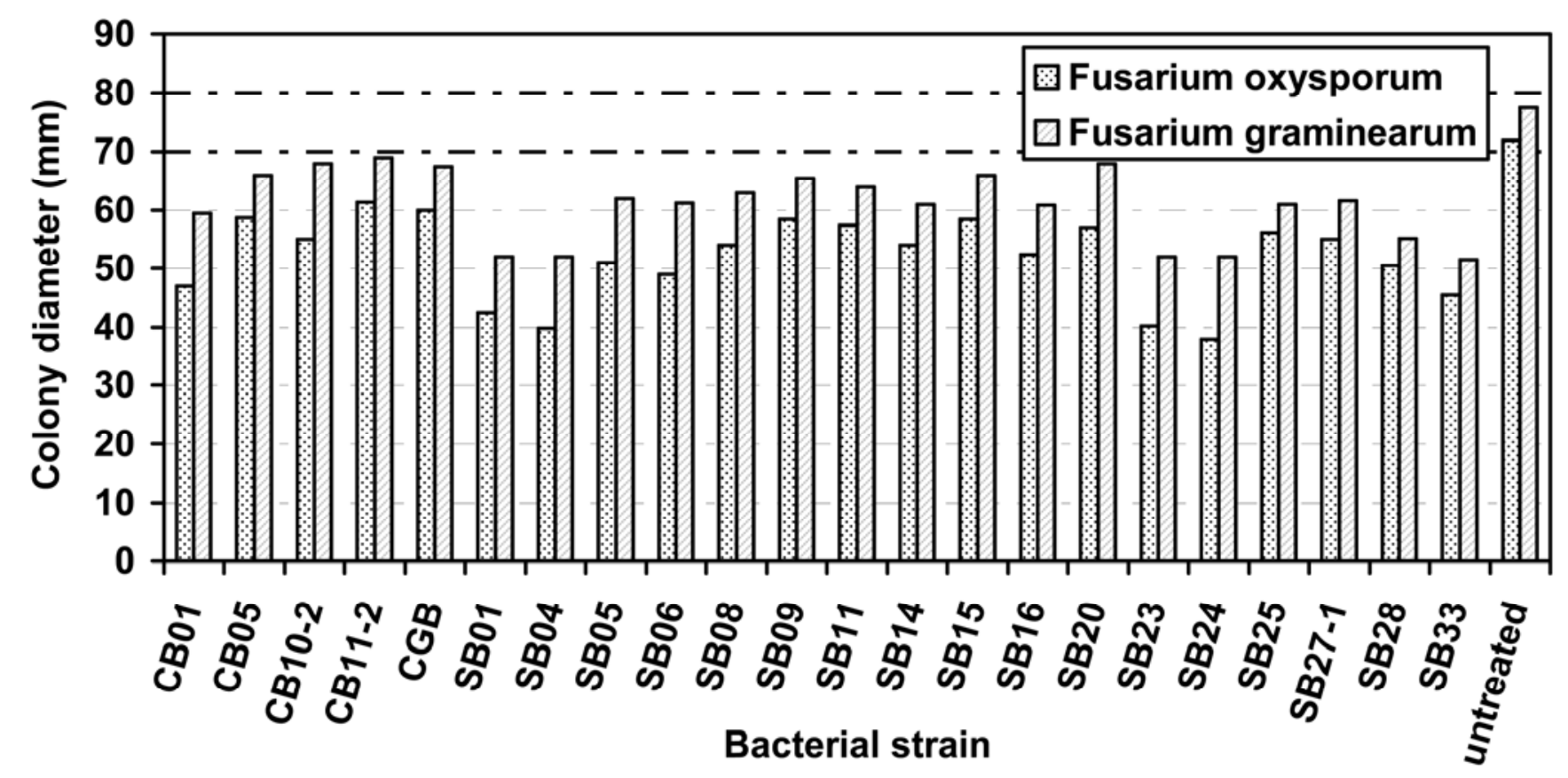

Fig. 2. Inhibition of Fusarium colonies by Bacillus subtilis strains. B. subtilis strains were isolated from soybean roots (SB), corn roots (CB), and soybean stem (CGB). Least significant difference $=3.4$ at $P \leq 0.05$ for Fusarium oxysporum and 5.7 for F. graminearum. 
3). Seven strains (CB01, CH22, SB01, SB04, SB23, SB24, and SB33) showed significant effectiveness in all four measured parameters (Table 3 ). The increases in growth parameters were not significantly different from the noninoculated plants.

Results from seed and soil treatment experiments demonstrated that eight strains

Table 2. Analysis of variance on effects of different Bacillus subtilis strains and trials on disease severity, seed emergence, plant height, and root dry weight of soybean in seed and soil treatments against the Fusarium oxysporum and $F$. graminearum root rots under greenhouse conditions

\begin{tabular}{|c|c|c|c|c|c|}
\hline \multirow[b]{2}{*}{ Rot, method, source } & \multirow[b]{2}{*}{ df } & \multicolumn{4}{|c|}{ Mean square ${ }^{\mathrm{y}}$} \\
\hline & & Root rot severity & Emergence & Plant height & Root dry weight \\
\hline \multicolumn{6}{|l|}{ F. oxysporum } \\
\hline \multicolumn{6}{|l|}{ Seed treatment } \\
\hline Strain & 27 & $4.1^{* *}$ & $216.4 * *$ & $11.0 * *$ & $439.3 * *$ \\
\hline Trial & 2 & $32.4 * *$ & $1,432.6 * *$ & $6,313.5^{* *}$ & $102,052.7 * *$ \\
\hline Strain $\times$ trial & 54 & 0.3 & 60.1 & 1.8 & $151.9^{*}$ \\
\hline Error & 252 & 0.2 & 58.8 & 1.4 & 104.8 \\
\hline \multicolumn{6}{|l|}{ Soil treatment } \\
\hline Strain & 27 & $4.3^{* *}$ & $124.0 * *$ & $12.8 * *$ & $564.2 * *$ \\
\hline Trial & 2 & $6.8^{* *}$ & $1,509.8 * *$ & $8,304.1 * *$ & $97,402.3 * *$ \\
\hline Strain $\times$ trial & 54 & 0.1 & 79.3 & 3.1 & $406.0^{*}$ \\
\hline Error & 252 & 0.1 & 60.5 & 2.3 & 277.3 \\
\hline \multicolumn{6}{|l|}{ F. graminearum } \\
\hline \multicolumn{6}{|l|}{ Seed treatment } \\
\hline Strain & 27 & $4.9^{* *}$ & $300.2 * *$ & $17.5^{* *}$ & $556.9 * *$ \\
\hline Trial & 2 & $30.6 * *$ & $4,149.8 * *$ & $8,101.1 * *$ & $6,703.5 * *$ \\
\hline Strain $\times$ trial & 54 & 0.3 & 75.5 & 1.2 & 120.3 \\
\hline Error & 252 & 0.2 & 71.3 & 1.3 & 129.7 \\
\hline \multicolumn{6}{|l|}{ Soil treatment } \\
\hline Strain & 27 & $3.5^{* *}$ & $112.7 * *$ & $28.1 * *$ & $544.9 * *$ \\
\hline Trial & 2 & $17.3 * *$ & $210.8 * *$ & $821.2^{* * *}$ & $113,602.2 * *$ \\
\hline Strain $\times$ trial & 54 & 0.2 & 37.9 & 4.8 & $415.5^{*}$ \\
\hline Error & 252 & 0.2 & 29.3 & 3.9 & 293.5 \\
\hline
\end{tabular}

${ }^{y}$ Seed emergence expressed in percentage was arcsine transformed before analysis of variance was performed; $*^{*}=P \leq 0.01 ; *=P<0.05 ;$ no asterisk $=P>0.05$.

${ }^{\mathrm{z}}$ Fusarium root rot, application method, source of variation.

(CB01, CH22, SB01, SB04, SB23, SB24, SB28, and SB33) provided better control for either $F$. oxysporum (Table 1) or $F$. graminearum root rot (Table 3). Among these, strains SB01, SB04, SB23, and SB24 were the most promising for protection of soybean plants against both Fusarium spp. in seed and soil treatments.

Soil treatment exhibited significantly $(P$ $\leq 0.05$ ) lower root rot severity with higher seed emergence, plant height, and root dry weight than seed treatments in experiments with $F$. oxysporum (Table 4). Similar trends were observed for $F$. graminearum, except for the root dry weight means, which did not significantly differ between seed and soil treatments (Table 4). A majority of strains showed greater reduction of root rot severity in soil treatment than in seed treatment experiments against both $F$. oxysporum root rot (Table 1) and $F$. graminearum root rot (Table 3 ). In addition, the number of effective bacterial strains was higher in soil treatment against both root rots. For example, strains $\mathrm{CH} 07$, CGB, SB09, CB11-2, CB10-2, SB16, SB25, and SB27-1 significantly reduced root rot severity in soil treatments but not in seed treatment against $F$. oxysporum root rot (Table 1).

\section{DISCUSSION}

This study demonstrated that 8 Bacillus strains (SB01, SB04, SB23, SB24, SB28,

Table 3. Effects of seed and soil treatments with Bacillus subtilis strains on Fusarium graminearum root rot on soybean, emergence, plant growth, and root dry weight under greenhouse conditions ${ }^{\mathrm{y}}$

\begin{tabular}{|c|c|c|c|c|c|c|c|c|}
\hline \multirow[b]{2}{*}{ Strain } & \multicolumn{2}{|c|}{ Root rot severity (0-5) } & \multicolumn{2}{|c|}{ Seed emergence $(\%)$} & \multicolumn{2}{|c|}{ Plant height $(\mathrm{cm})$} & \multicolumn{2}{|c|}{ Root dry weight (mg/plant) } \\
\hline & Seed & Soil & Seed & Soil & Seed & Soil & Seed & Soil \\
\hline Noninoculated & 0 & 0 & 96.5 & 96.5 & 20.6 & 20.6 & 94.6 & 94.6 \\
\hline CB01 & 1.9 & 1.3 & 93.8 & 92.7 & 17.3 & 20.2 & 83.5 & 92.6 \\
\hline CB05 & 2.7 & 2.1 & 85.0 & 87.2 & 17.9 & 16.9 & 78.2 & 74.4 \\
\hline CB10-2 & 2.6 & 2.6 & 81.8 & 78.8 & 16.0 & 16.4 & 78.3 & 78.4 \\
\hline CB11-2 & 3.0 & 2.4 & 85.8 & 88.7 & 16.9 & 16.7 & 81.4 & 81.9 \\
\hline CGB & 3.2 & 2.8 & 79.8 & 77.0 & 15.9 & 15.7 & 82.3 & 84.6 \\
\hline $\mathrm{CH} 07$ & 2.9 & 2.5 & 85.0 & 85.2 & 17.1 & 16.0 & 76.1 & 79.1 \\
\hline CH10 & 2.8 & 2.3 & 83.6 & 89.6 & 16.8 & 16.9 & 75.9 & 78.4 \\
\hline CH19 & 2.8 & 2.4 & 81.5 & 83.2 & 16.9 & 16.8 & 83.1 & 81.7 \\
\hline $\mathrm{CH} 22$ & 2.0 & 1.4 & 91.4 & 91.9 & 17.9 & 20.2 & 82.4 & 91.3 \\
\hline SB01 & 1.9 & 1.1 & 93.2 & 95.4 & 18.5 & 20.6 & 88.9 & 96.2 \\
\hline SB04 & 1.8 & 1.2 & 94.5 & 92.4 & 18.4 & 20.6 & 92.5 & 92.5 \\
\hline SB05 & 2.4 & 2.0 & 93.2 & 87.2 & 17.7 & 16.9 & 82.9 & 80.9 \\
\hline SB06 & 2.4 & 1.9 & 90.0 & 89.9 & 16.9 & 17.7 & 83.9 & 81.1 \\
\hline SB08 & 2.8 & 2.0 & 82.7 & 86.4 & 16.3 & 17.6 & 86.1 & 85.0 \\
\hline SB09 & 3.0 & 2.9 & 80.1 & 84.8 & 16.5 & 16.1 & 70.6 & 76.1 \\
\hline SB11 & 2.3 & 1.9 & 85.1 & 88.7 & 17.3 & 17.2 & 82.7 & 84.8 \\
\hline SB14 & 2.5 & 2.0 & 89.0 & 90.0 & 17.7 & 16.5 & 83.4 & 83.7 \\
\hline SB15 & 2.7 & 2.2 & 84.0 & 88.7 & 17.7 & 17.7 & 80.3 & 82.1 \\
\hline SB16 & 2.7 & 2.3 & 77.8 & 80.5 & 17.5 & 17.4 & 75.6 & 82.8 \\
\hline SB20 & 3.0 & 2.2 & 86.4 & 87.5 & 16.1 & 16.3 & 74.6 & 76.9 \\
\hline SB23 & 1.8 & 1.3 & 92.4 & 95.1 & 19.1 & 18.8 & 87.1 & 93.7 \\
\hline SB24 & 1.7 & 0.9 & 94.7 & 95.8 & 19.9 & 19.8 & 96.6 & 93.9 \\
\hline SB25 & 2.7 & 2.1 & 81.4 & 90.9 & 16.8 & 15.9 & 83.0 & 80.4 \\
\hline SB27-1 & 3.0 & 2.4 & 81.3 & 86.8 & 16.3 & 16.3 & 82.1 & 75.9 \\
\hline SB28 & 2.4 & 1.5 & 88.9 & 92.3 & 17.8 & 19.0 & 80.7 & 82.7 \\
\hline SB33 & 1.9 & 1.4 & 91.3 & 94.0 & 17.0 & 19.5 & 84.6 & 93.5 \\
\hline Untreated & 3.3 & 3.3 & 78.4 & 78.4 & 16.8 & 16.8 & 80.4 & 80.4 \\
\hline $\mathrm{LSD}^{\mathrm{z}}$ & 0.3 & 0.3 & 9.2 & 8.2 & 0.91 & 1.1 & 8.1 & 10.8 \\
\hline
\end{tabular}

${ }^{\mathrm{y}}$ B. subtilis strains were isolated from soybean roots $(\mathrm{SB})$, corn roots $(\mathrm{CB}$ and $\mathrm{CH})$, and soybean stem $(\mathrm{CGB})$. Noninoculated $=$ healthy plant without any inoculation and Untreated = plant roots only treated with inoculum of Fusarium oxysporum. Data were means of three trials.

${ }^{\mathrm{z}} \mathrm{LSD}=$ least significant difference $(P=0.05)$. 
SB33, CB01, and CH22) out of 26 B. subtilis strains tested provided significant and consistent protection of soybean plants against $F$. oxysporum or $F$. graminearum root rot by seed or soil treatments under greenhouse conditions. Root rot severity caused by two Fusarium spp. was significantly reduced by these bacterial strains, with significant increases in seed emergence, plant height, or root dry weight compared with untreated plants. Strains SB01, SB04, SB23, and SB24 consistently showed significant positive results for the four parameters studied for $F$. oxysporum and $F$. graminearum root rot in both seed and soil treatments. The results from these seed and soil experiments suggest that these novel strains of $B$. subtilis are effective biocontrol agents against the Fusarium root rot pathogens and may have potential application as biocontrol agents in commercial soybean production. In addition, the greenhouse tests indicated that the method of bacterial application could affect the effectiveness with which these strains protect soybean seedlings against soilborne Fusarium pathogens. Based on root rot severity reduction and increases of seed emergence, plant height, and root dry weight, soil treatment seems to be a more effective method of application against both root rots than seed treatment.

In dual-culture studies, we demonstrated that some of the bacterial strains and their cell-free filtrates significantly inhibited the mycelial growth and spore germination of $F$. oxysporum and $F$. graminearum in vitro. The presence and size of the inhibition zones have, in most cases, been used as major criteria in the selection of biocontrol agents and have been viewed as evidence of the production of antifungal secondary metabolites by bacterial strains $(6,11)$. Production of inhibition zones by bacteria selected in our study might suggest that these new $B$. subtilis strains suppress Fusarium spp. mycelial growth by the production of some diffusible inhibitory substances in the medium. Bacillus spp. have been reported to produce a large number of peptide antibiotics and antifungal secondary metabolites representing at least 25 different basic chemical structures that inhibit mycelial growth of various pathogens by diffusion in culture medium (16). A better understanding of the anti- fungal compounds produced by these new bacterial strains that are involved in the protection of soybean plants against Fusarium root rots is necessary so as to investigate and characterize factors that could affect the performance of these bioagents under field conditions.

Studies of other pathosystems showed that delivery of $B$. subtilis via seed either improved plant growth significantly and decreased infection of pathogens (20) or did not show effects on plant growth. In our study, although some B. subtilis strains significantly increased plant height compared with pathogen-treated plants, plant height was not significantly different from that of plants not inoculated with the pathogens. This suggests that none of our B. subtilis strains seemed to promote plant growth in both seed and soil treatments. This is an indication that the strains identified in the present study were involved primarily in Fusarium root rot disease suppression.

The B. subtilis strains in the current study controlled $F$. oxysporum or $F$. graminearum root rot to different degrees which were, to some extent, dependent on the method of bacterial application. In general, the soil treatments provided better protection against both Fusarium root rot pathogens than the seed treatment based on severity, seedling stands, plant height, and root dry weight. This may be due to differential survival and colonization on soybean roots by the bacterial strains in seed and soil treatments. Previous studies in biocontrol of root rot diseases have demonstrated that the colonization of biocontrol agents at target sites on the root system is a prerequisite for suppression of plant pathogen infection $(2,19,27)$. Szczech and Shoda (24) reported that the poor protection by $B$. subtilis against Rhizoctonia damping-off on tomato seed could be caused by insufficient production of antifungal compounds to suppress the pathogen because bacterial colonization of soil around seed coated with B. subtilis was lower than in soil mixed with bacteria. In contrast, mixing bacteria with soil helped to establish a high number and uniform population of $B$. subtilis in soil and rhizosphere, enabling frequent contact between the pathogens and antifungal bacteria.

We observed, under greenhouse conditions, that the bacterial strains isolated from soybean roots were more powerful in controlling $F$. oxysporum or $F$. graminearum root rots of soybean than those from corn roots. Only 4 (CB01, CB05, CB11-2, and $\mathrm{CB} 10-2$ ) of the 50 strains from corn roots were able to inhibit $F$. oxysporum and $F$. graminearum at an effective level comparable with strains from soybean roots (data not shown). In the seed and soil treatments under the greenhouse conditions, only CB01 showed comparable effectiveness with strains from soybean roots with regard to the parameters studied. Similarly, four strains (CH07, CH10, $\mathrm{CH} 19$, and $\mathrm{CH} 22$ ) isolated from corn roots exhibited good inhibition to mycelial growth of $F$. graminearum in the previous experiment (data not shown) but only $\mathrm{CH} 22$ provided comparable effectiveness with those strains from soybean roots in seed and soil treatments against both Fusarium root rots in the current study. This might suggest that the efficacy of a biocontrol agent is associated with its origin. Cook (5) reported that microorganisms isolated from the root or rhizosphere of a specific crop may better adapt to that crop and provide better control of diseases than organisms originally isolated from other plant species. Our results support the findings of Cook (5) because better protection of Fusarium root rots of soybean were recorded by bacterial strains from soybean roots.

Although bacterial strains tested in this study showed significant efficacy against Fusarium root rot pathogens under greenhouse conditions, this might not suggest that the strains will provide similar effectiveness in field conditions. Several studies have indicated that the efficacy of microbial control of plant pathogens is dependent on environmental conditions in the field. Survival of bacteria and the production of antifungal components by these bacteria are greatly affected by soil environmental conditions such as soil type and $\mathrm{pH}$ values (23). In order for these bacteria to be used under field conditions, their ecological fitness, establishment to survive, and function within particular conditions must be studied. In addition, mechanisms of action, ecological characteristics, and interaction with soil and rhizosphere microbial communities are also information required for their practical application.

Table 4. Effectiveness comparison of seed and soil treatments with Bacillus subtilis under greenhouse conditions against root rots caused by Fusarium oxysporum and $F$. graminearum $^{\mathrm{z}}$

\begin{tabular}{|c|c|c|c|c|c|c|c|c|}
\hline \multirow[b]{2}{*}{ Treatment } & \multicolumn{4}{|c|}{ Fusarium oxysporum root rot } & \multicolumn{4}{|c|}{ Fusarium graminearum root rot } \\
\hline & $\begin{array}{c}\text { Root rot } \\
\text { severity }(0-5)\end{array}$ & $\begin{array}{c}\text { Emergence } \\
(\%)\end{array}$ & $\begin{array}{l}\text { Height } \\
(\mathrm{cm})\end{array}$ & $\begin{array}{l}\text { Root dry weight } \\
\text { (mg/plant) }\end{array}$ & $\begin{array}{c}\text { Root rot } \\
\text { severity }(0-5)\end{array}$ & $\begin{array}{c}\text { Emergence } \\
(\%)\end{array}$ & $\begin{array}{l}\text { Height } \\
(\mathrm{cm})\end{array}$ & $\begin{array}{l}\text { Root dry weight } \\
\text { (mg/plant) }\end{array}$ \\
\hline Seed & $1.9 \mathrm{a}$ & $72.1 \mathrm{~b}$ & $18.2 \mathrm{~b}$ & $82.2 \mathrm{~b}$ & $2.4 \mathrm{a}$ & $69.1 \mathrm{~b}$ & $17.5 \mathrm{~b}$ & $83.1 \mathrm{a}$ \\
\hline Soil & $1.6 \mathrm{~b}$ & $73.5 \mathrm{a}$ & $18.7 \mathrm{a}$ & $84.3 \mathrm{a}$ & $1.9 \mathrm{~b}$ & $70.7 \mathrm{a}$ & $17.8 \mathrm{a}$ & $83.7 \mathrm{a}$ \\
\hline LSD & 0.1 & 1.1 & 0.2 & 1.9 & 0.1 & 1.1 & 0.2 & 1.8 \\
\hline
\end{tabular}

${ }^{\mathrm{z}}$ Data were means of 26 Bacillus subtilis strains in three trials. Numbers in a column followed by the same letters are not significantly different at $P=0.05$. LSD $=$ least significant difference. 


\section{ACKNOWLEDGMENTS}

We thank the Chemtura Canada Co./CIE for financial support of this study and Y. Chen, S. Wellington, and F. Aiston for technical assistance.

\section{LITERATURE CITED}

1. Amer, G. A., and Utkhede, R. S. 2000. Development of formulations of biological agents for management of root rot of lettuce and cucumber. Can. J. Microbiol. 46:809-816.

2. Bull, C. T., Weller, D. M., and Thomashow, L. S. 1991. Relationship between root colonization and suppression of Gaeumannomyces graminis var. tritici by Pseudomonas fluorescens strain 2-79. Phytopathology 81:954-959.

3. Chao, W. L., Nelson, E. B., Harman, G. E., and Hoch, H. C. 1986. Colonization of the rhizosphere by biological control agents applied to seeds. Phytopathology 76:60-65.

4. Collins, D. P., and Jacobsen, B. J. 2003. Optimizing a Bacillus subtilis isolate for biocontrol of sugar beet cercospora leaf spot. Biol. Control 26:153-161.

5. Cook, R. J. 1993. Making greater use of introduced microorganisms for biological control of plant pathogens. Annu. Rev. Phytopathol. 31:53-80.

6. Crawford, D. L., Lynch, J. M., Whips, J. M., and Ousley, M. A. 1993. Isolation and characterization of actinomycetes antagonists of fungal root pathogen. Appl. Environ. Microbial. 59:3899-3909.

7. De Weger, L. A., van der Bij, A. J., Dekkers, L. C., Simons, M., Wijffelman, C. A., and Lugtenberg, B. J. J. 1995. Colonization of the rhizosphere of crop plants by plant-beneficial pseudomonads. FEMS Microbiol. Ecol. 17:221-228.

8. Ghonim, M. I. 1999. Induction of systemic resistance against Fusarium wilt in tomato with the biocontrol agent Bacillus subtilis. Bull. Fac. Agric. Univ. Cairo 50:313-328.

9. Gray, L. E., and Achenbach, L. A. 1996. Severity of foliar symptoms and root and crown root of soybean inoculated with various isolates and inoculum rates of Fusarium solani. Plant Dis. 80:1196-1199.

10. Haas, D., Blumer, C., and Keel, C. 2000. Biocontrol ability of fluorescent pseudomonads genetically dissected: importance of positive feedback regulation. Curr. Opin. Biotech- nol. 11:290-297.

11. Jackson, A. M., Whips, J. M., and Lynch, J. M. 1991. In vitro screening for identification of potential biocontrol agents of Allium white rot. Mycol. Res. 95:430-434.

12. Larkin, R. P., and Fravel, D. R. 1998. Efficacy of various fungal and bacterial biocontrol organisms for control of Fusarium wilt of tomato. Plant Dis. 82:1022-1028.

13. Larkin, R. P., Hopkins, D. L., and Martin, F. N. 1996. Suppression of Fusarium wilt of watermelon by nonpathogenic Fusarium oxysporum and other microorganisms recovered from a disease suppressive soil. Phytopathology 86:812-819.

14. Mao, W., Lewis. J., Hebber, P., and Lumsden, R. 1997. Seed treatment with a fungal or a bacterial antagonist for reducing corn damping-off caused by species of Pythium and Fusarium. Plant Dis. 81:450-454.

15. Mao, W., Lumsden, R. D., Lewis, J. A., and Hebbar, P. K. 1998. Seed treatment using preinfiltration and biocontrol agents to reduce damping-off of corn caused by species of $P y$ thium and Fusarium. Plant Dis. 82:294-299

16. Mutaz, M. A., and Hasnain, S. 2006: Simple and rapid isolation of a novel antibiotic from Bacillus subtilis Mz-7. J. Liq. Chromatogr. R. T. 29:639-647.

17. Nelson, B. D. 1999. Fusarium blight or wilt, root rot, and pod and collar rot. Pages 35-36 in: Compendium of Soybean Diseases, 4th ed. G. L. Hartman, J. B. Sinclair, and J. C. Rupe, eds. American Phytopathological Society, St. Paul, MN.

18. Pang, L., Close, M., Noonan, M., and Rhodamine, W. T. 1998. B. subtilis transport through an alluvial gravel aquifer. Ground Water 36:112-122.

19. Parke, J. L. 1990. Population dynamics of Pseudomonas cepacia in the pea spermosphere in relation to biocontrol of Pythium. Phytopathology 80:1307-1311.

20. Reddy, M. S., and Rahe, J. E. 1989. Growth effects associated with seed bacterization not correlated with populations of Bacillus subtilis inoculant in onion seedling rhizospheres. Soil Biol. Biochem. 21:373-378

21. Rorberti, R., and Selmi, C. 1999. Biological control of plant pathogens by Bacillus subtilis. Inf. Fitopatol. 49:15-21.
22. Ryder, M. H., Zhinong, Y., Terrace, T. E. Rovira, R. D., Wenhua, T., Carrell, R. L., Yan, Z., and Tang, W. 1999. Use of strains of Bacillus isolated in China to suppress take-all and Rhizoctonia root rot, and promote seedling growth of glasshouse-grown wheat in Australian soils. Soil Biol. Biochem. 31:19-29.

23. Schmidt, C. S., Agostini F., Simon A. M., Whyte, J., Townend, J., Leifert, C., Killham, K., and Mullins, C. 2004. Influence of soil type and $\mathrm{pH}$ on the colonization of sugar beet seedlings by antagonistic Pseudomonas and Bacillus strains, and their control of Pythium damping-off. Eur. J. Plant Pathol. 110:10251046.

24. Szczech, M., and Shoda, M. 2006. The effect of mode of application of Bacillus subtilis RB14-C on its efficacy as a biocontrol agent against Rhizoctonia solani. J. Phytopathol. 154:370-377.

25. Utkhede, R. S., Koch, C. A., and Menzies, J. G. 1999. Rhizobacterial growth and yield promotion of cucumber plants inoculated with $P y$ thium aphanidermatum. Can. J. Plant Pathol. 21:265-271.

26. Wang, D., Kurle, J. E., Estevez de Jensen, C. and Percich, J. A. 2004. Radiometric assessment of tillage and seed treatment effect on soybean root rot caused by Fusarium spp. in central Minnesota. Plant Soil 258:319-331.

27. Weller, D. M. 1988. Biological control of soilborne plant pathogens in the rhizosphere with bacteria. Annu. Rev. Phytopathol. 26:379-407.

28. Wrather, J. A., Anderson, T. R., Arsyad,. D. M., Tan, Y., Ploper, L. D., Porta-Puglia, A., Ram, H. H., and Yorinori, J. T. 2001. Soybean disease loss estimates for the top ten soybeanproducing countries in 1998. Can. J. Plant Pathol. 23:115-121.

29. Xue, A. G., Cober, E., Morrison, M. L., Voldeng, H. D., and Ma, B. L. 2006. Effect of seed treatments on emergence, yield, and root rot severity of soybean under Rhizoctonia solani inoculated field conditions in Ontario. Can. J. Plant Sci. 87:167-173.

30. Zimmer, J., Issoufou, I., Schmiedeknecht, G., and Bochow, H. 1998. Population dynamics of Bacillus subtilis as biocontrol agent under controlled conditions. Part II, pages 489-495 in: Proc. 50th Int. Symp. Crop Prot. Gent, Belgium. 